\author{
RAFFAELE MILANI
}

\title{
THE BIRTH OF THE AESTHETICS OF LANDSCAPE
}

Kenneth Clark (Landscape into Art) asserted that we are surrounded by things we have not made and that have a life and a structure of their own (trees, meadows, rivers, hills, sky etc).

The pleasure that all this has always given us is connected with our sentiments. Landscape painting. succeeded in interpreting all of this, above all in the Nineteenth century, offering a true conception of nature.

The relation between landscape and nature is evident, but at the same time they are two distinct ideas. Landscape expresses, as Simmel argued. an ethical reality and belongs to human life, to the world of the accidental. to the possible, to an experience that we can change. Nature, on the other hand. is the infinite connection of things, the uninterrupted birth and destruction of form, the fluctuating unity of happening which expresses itself in the continuity of temporal and spatial existence.

Simmel declared that the configuration of the world after the Middle Ages and the decline of symbolic thought showed us the landscape in nature for the first time: before the Italian Renaissance. man did not possess a sense of landscape seen as a combination of cletails bound up with a mood. It was not in fact until the $15^{\text {th }}$ and $16^{\text {th }}$ centuries that the autonomous contemplation of landscape began to be manifested in landscape painting. He added. however, that since the $18^{\text {th }}$ century the evolution of society, technique and ethics had caused a laceration in human culture, while aesthetic form had succeeded in finding richness and reconciliation in landscape with respect to nature. Although landscape is limited to the view of what is indiviclual, it essentially remains linked to nature and to its unity and totality. When we observe and admire a landscape, the process through which it is perceived as a work of art is intensified and purified, going beyond the relation between landscape and painting. The observer acts as an artist does. though to a lesser degree, chooses and selects from a carotic and infinite workd. but with a unifying intent. A landscape is no longer the sum of single natural objects, but a work of art in its initial stage. Through this concept and perception, the union of the act of seeing and the act of feeling is pre- 
figured. The unity of different data hinges on the principle of the Stimmung of landscape. Stimmung, a psychical process, is a property of landsape, in other words, landscape which has been transfigured into a spiritual form. The unitary representation of a thing and its feeling merge. Landscape is nature revealing itself aesthetically.

It is worth pointing out that the modern sentiment of landscape was first revealed in Lascensione al Monte ventoso by Petrarch. The interpretation of nature found in it was to evolve in the Eighteenth Century and was to combine the discorery of variety of sites and the emotions of historical or mithological past. This subject was explained very well by Shama when he describes the aesthetic pleasure deriving from the image of the Alps citing Turner's painting of Hannibal's crossing: The evocation of that crossing aroused great emotion in Eighteenth Century writers and intellectuals from Gray to Walpole, as it was informed by historical and literary memory (Silio,Livio) and the spirit of imagination in the style of Salvator Rosa. The picturesque traveller thus felt pervaded by what may be called aesthetic heroism in visiting these itineraries. In Petrarch this sentiment had grown in the light of historical and mythological memory.

I shall attempt to find the convergence of all of the problems relating to painting and representation within a framework of ideas underlying the aesthetics of landscape.

Its origins and development were conditioned by the fashion of travelling, the figure of the connoisseur, veduta painting, the aesthetic appreciation of the Alps and of volcanoes. Another influence was aesthetic categories: the idea of the picturesque, characterized by the irregularity, variety, intricacy and roughness of a wild and disorderly nature, the terror of the sublime characterized by the danger aroused by greatness, darkness, passion, and which also apply to exotic sensibility. This condition gave rise to an aesthetic feeling of landscape that is different from a more remote feeling of nature (from Homer, Ovid, Virgil, etc.). The painter and the observer wish to experience the aesthetic perception of details, particulars, and the connection between glance and frame. These points all have to do with a new definition of sensibility elevated to a higher aesthetic order and will be discussed more fully in relation to Rosario Assunto's theory (Introduzione alla critica del paesaggio) in which landscape criticism is compared to art criticism. Before Assunto, another Italian philosopher (Antonio Banfi) had grasped the significance of the revolution in taste. and though, expounding the "Romantic concept of natural beauty", which is irregular, unusual, sudden and demon- 
ic. showing the relationship between spontaneous aesthetic intuition and artistic intuition.

Aesthetic cliscovery of landscape in Europe is fairly recent and clates back to the eighteenth century when the theat of inclustrialization becance visible and tangihle. To put it succinctly, landscape is the overall view an observer (immobile or in motion) has of his surrounclings from a given angle. However the focus on landscape in its varied forms, like the pleasure one derives from observing it, delineates a complex shift in sensibility and thinking from a historical and cultural viewpoint open to profound and metaphorical meanings bound up with being. The landscape thus can be seen as a concept concerning numerous disciplines. If we restrict our analysis to the area of atesthetics, to the taste for nature which cleveloped cluring the Age of Reason, the scene which immediately unfolds before us presents the picturesque als a vision of nature.

Historically, the concept of the picturesque has been interpreted as the reappraisal and view of nature from the point of view of an aesthetic reflection on beauty. Signs of this research on landscape and the environment can be traced even prior to its theorization in Great Britain at the end of the 18 th century to Vasari when this term was used merely to indicate a technique in painting "alla pittoresca". Even then these signs were highly particular ways of clepicting life and objects in relation to the perceptual and psychological activity of the subject. During the 17 th century, and above all cluring the 18 th century, the picturesque progressively developed into a taste through a pressing visual strategy by virtue of what was "proper to painting and painters". Thus in the complex transition from the classical to the romantic, we witness the aesthetic discovery of landscape parallel to the positive cliscovery of the natural sciences. Moreover, because of the reasons mentioned above, a fertile exchange between the eye which observes and contemplates (the natural eye) and the selective eye of painting (the pictorial eye) caln be discerned in these pathways. This exchange is also extended to the relation between creation and utilization, between pátinter and observer. Since psychological processes are linked to the evolution of taste, seeing ( $\mathrm{a}$ an referring to the historico-perceptual strategics of the picturesque) implies a view; whereas contemplating and representing are seen as promoting a poetic broadening of perception, giving rise to an aesthetic emotion and an authentic vision.

In its search for effect and its taste for ruins, the picturescue marks the passage from the Baroque to Romanticism as it clistances itself from reason and from the rules of Classicism, relying on frecelom of invention. It does 
not convey a profound authentic feeling, but a suggestive staging of curiosities and impressions from which unusual and powerful images of wild and spontaneous nature arise. During the 18th century in Great Britain the picturesque mingled with the sublime theorized by Burke, with the Gothic and with the pastoral tradition of literature. It is a plural concept in which beany' in painting merges with beamy' in nature. This can be seen in the visual arts, architecture, gardening, literature (visual descriptivism) and the taste for travel and faraway places.

In this investigation the picturesque is probably also the first important theory concerning the landscape. Outside Europe, in China for example, the aesthetic interest in the landscape (an interest in the cletails of seeing) flourished much earlier, about a millenium earlier, and led to the view of man and nature conjoined within a cosmic, spiritual design. Behind its evolution and its visual discovery seen as a framework of observation, composition and points of view (lights, panoramas, scenes), a description unfolds which in time selects, improves, orders, establishes criteria, sets up comparisons, and elaborates ideas. From the feeling of wonder experienced by John Dennis (1693), John Addison (1705), Anthony Shaftesbury (1709) and George Berkeley at the sight of overhanging rocks, roaring torrents, rugged cliffs. waterfalls, and shadowy forests to the research conducted by William Gilpin. Uvedale Price and Richard Payne Knight anticipating romantic fren$2 y$, an aesthetic theory emerges halfway between our imagination and the pleasure of sight and the senses. It is a reasoned sensibility founded on the value attributed to the irregularity, variety, intricacy and roughness of a wild and disorderly nature, an aesthetic pleasure which relies on spontaneity and caprice. Nature is a spectacle, a theater of the unusual, the stage of our imaginings, a point of departure and return. The astonishment expressed by Goethe (1779; letter) and Hegel (1795) before the view of the Bernese Alps, but particularly before the view of the waterfall of Staubbach, can easily be read as a romantic pássion emerging from a pleasure typical of picturesque taste.

The Picturesque tourist was dramn towards solitary and uncommon landscapes, architectural ruins and tangled regetation. The description of landscapes becomes a composition of selected images, a classification of events and impressions. conjoined judgements made explicit, an elaboration of general concepts and practical interventions, a path of analogies and memories, al project of variable patterns, a focus on particular knowledge to attain a heightened sensibility. In the writings on the picturesque at the end of the I Sth century and at the beginning of the 19th century a broad and systematic interpretation of the world around us and of vegetable, animal and 
human life began to take shape. What we lind interesting today, despite the differences between the various atuthors and their cultural and temporal backgrounds, is the strategy adopted in the observation of nature (a strategy not only connected with the "artem celare" theory), the measures to improve its arrangement and the pleasures that this arouses also in relation to spectacular outcomes. effect and feeling. It was al reordering that follow's the laws of nature and the work of man, an illusion worth returning to in order to reformulate our attitudes. This illusion was to appear again in the observations of Schinkel and Constable and later expanded in a project for a new sensibility in philosophy.

Many things have changed since the end of the 18th century, but this profound feeling for nature has not died out, for we still seek an intimate contact with the landscape. seen and experienced as a whole by our minds and bodies. Betreen the morld of nature and the world of ant which reflects it. beauty, grace, the sublime. the picturesque and other aesthetic ideas continue to spread their seeds and suggest infinite forms to the imagination. To perceive the landscape undoubtedly brings into play an aesthetic act which forms our culture and history in general.

It entails more than seeking landscape in art and literature. Betreen the end of the $19^{\text {th }}$ century and the beginning of the $20^{\text {th }}$. another great transformation took place starting with the impressionists and macchiaioli, down to the expressionists, cubists and abstract artists. Cezanne. Monet, Gauguin. Morandi, as Klimt. Previati, Kandinski or Mondrian all have a legitimate place in this discussion since they represented a revolution in the approach to seeing and feeling. The aesthetic problem of landscape. howerer, is not restricted to the comparison between the arts.

The teachings of Rosario Assunto in Italy was decisive in pointing out how the landscape and its interpretation promote a high degree of civilization in the evolution of taste. He reminded us that the landscape contains the traces of the identity of nature and of the spirit in proposing sensibilities illuminated in turn by various aesthetic categories. Contemplation. he asserted. is not pure fantasy. but an exercise in feeling. Certain morphologies of landscape can become traces of poetics. or ideal indications. Beneath these analyses and the sentiment of nature lies a criticism whereby material being is the result of a working process equal to aesthetic being. Lindscape is an aesthetic institution by virtue of itself, of literary and travel testimonies, of visual arts and of the subject's imagination. This taties us back to the relation between nature and culture within which the ecological comparison falls. In Assunto's thought landscape is the form of culture and history, the 
form in which culture and history have been absorbed. As for the problem regarding the value of natural beauty, he opposed the views expessed by Croce (Aesthetica in muce) who reiterated the traditional separation between natural and artistic beauty. Assunto (Introduzione alla critica del paesaggio) also posed the question as to whether it is possible to elaborate a "landscape criticism" comparable to ant criticism. This would give rise to a landscape criticism centering on the feeling of nature involving philosophical reality, culture, and the vision of the world in a connection supported by the aesthetic ideal. This ideal underlies the discovery of nature and transforms man into an artist. As the mediator between nature and history, man today must flee from the city of Prometheus founded on economism, technical rationalism and scientism and seek shelter in the city of Anfione who softenect the rationality of building with music and song.

In recent years the attention has been focused not so much on the comparison between aesthetic sensibility and artistic production, on the aims of philosophy and the "objectivity" of natural beauty as on the fact that nature itself maly be perceived as a work of art. As a result, one needs to go beyond the perspective of a study of landscape in art, as Kenneth Clark did, or conversely, of art in landscape, as the theoreticians of the picturesque at the end of the $18^{\text {th }}$ century proposed. Moreover, even the difference between gardens and the natural and cultural landscape, the latter being the result of the work of man who molded it, is for the most part interpreted today as an art of nature capable of encompassing garden and landscape. The landscape (natural or rural) of the entire world could be viewed as a garden, and all the gardens of the world, even the smallest ones, could be considered landscapes in relation to the world in its totality.

Let us now turn to some Italian themes. As regards the problem of the English garden, it is important to recall Ippolito Pindemonte's Dissertazione su i giardini inglesi e sul merito di ciò all Italia (1792). In this paper, which may be defined an alesthetic treatise on gardening, Pindemonte argues that Italy was the first country to create this kind of garden as an image of nature as such. The image is first found in Tasso and later appears in Milton. To support his argument, Pindemonte cites the description of the Armida gardens in Gensalemme liberata, cap. XVII, ottave, IX,X.2

The theory of a spontaneous and extraordinary landscape emerges when Tasso declares that nature may assume the role of the artist who enjoys imitating he who imitates nature, in other words, ast (l'arte, che tutto fa, nulla si scopre"). Behind these words lies the principle of art which conceals itself. It is the famous formula "artem celare" which theorized naturalness and 
spontaneity while concealing artifice and illusion, found in numerous treatises of the $I^{\text {th }}$ and $16^{\text {th }}$ centuries and is parallel to the theory of "sprezzatura". 3

The problem of imitation, representation and inventive caprice is able to make us believe that there is a true and spontancous revelation of nature. Throughout the $18^{\text {th }}$ century false perspectives, the effects of trompe-loeil, veduta painting, views, the pleatsure of false ruins, the Clatude Lorrain lens, the $b a b a$ and improvement techniques are clesigned to cleceive us in that they are aesthetic strategies of illusion. In this game art dissimulates, hides conceals itself, pretends it is not there.

In this treatise Pindemonte launches the new taste which was spreading in the "veneto" region regarding the subject of gardens. This success is proven by the fact that after several years, in 1817 to be precise, in Verona a collection of papers by Luigi Mabil, Melchiorre Cesarotti. Vincenzo Malacarne was published on this very subject (Operette di vari autori intomo ai giardini inglesi ossia moderni). In short. at the turn of the 19th century there was an important debate on garden also in Italy.

Receptive to the new aesthetic ideas from England. but against both Chambers and $\mathrm{H}$. Walpole, Pindemonte declares Tasso the inventor of this artistic genre: the landscape garden. It is evident, however, that there are no grounds to support this claim, as explain Venturi (117-120) and Basile (340345). The garden Tasso describes is in reality a mannerist garden and closely resembles the gardens of Bomarzo and Pratolino The issue of Italian primacy aside, it can be argued that certain aesthetic suggestions of the Armidat gardens, as of the mannerist gardens in general, contains elements which seen to anticipate some aspects of Romantic authors.

These excellent points for a discussion of the beatuty of landscape, its irregularity, variety, order, and stirring image, raise the question as to whether an aesthetics of landscape exists, or can exist, and when it was born. Through means of artistic representations, cultural habits and the life of forms we therefore turn our thoughts to an aesthetics which categorizes and values elements, things. material geological aggregates and grassy expanses from the point of view of taste. What then do we think of when we think of the aesthetics of landscape? We certainly think of a feeling and a judgement of taste related to nature, ethics, freedom. the artilicial, imitation, the imagination and sensory experience. At the same time this map of relations is informed by reflections on what is ancient and what is modern. on what appears to be lasting and what proves to be improvised or ephemeral, but it is also informed by the meaning of human work from the 
garden to cultivations, as well as a criticism of the observing eye: is it the individual that activates the beauty of the things around him/her, or do these things reveal their beatuty independently of the individual? During the $18^{\text {th }}$ century all these themes formed a systematic intermingling within which a categorical spectrum of taste was found: beauty, grace, the sublime, the picturesque, the "je ne sais quoi", the new-Gothic. These complex ideas together with the great historico-stylistic models such as the classic, the baroque, the rococò, and the romantic were closely connected with the reception of landscape and with the sentiment of nature. Every landscape in fact belongs to man, his activity, his freedom, and his being a maker who creates, modifies, constructs and transforms by means of art and technique. We know that a work of art, as distinct from a natural effect, is the work of man. However, landscape too can itself be considered the result of art, the effect of man's doing, acting and feeling through freedom (landscape is a manifestation of human freedom in nature, as J. Ritter states in Landschaft...), through the categorization of so-called "natural beauty". The first landscape theorists like Hirschfeld and Girardin had also thought along these lines. It is not difficult to comprehend that it is not only an aesthetic but also an ethical reality. As Martin Schwind asserted, landscape is a work of art comparable with every other creation of man, but much more complex: whereas a painter paints a picture, a poet writes a poem, the people as a whole create a landscape, constitute the deep reservoir of their spirit. The spirit, as Kerenyi explains, seeks landscape; there is a very close relationship between the two, an interpenctration of nature and culture: landscape educates and inspires the creative act.

Landscape is not space, it is not the green area of city parks, it is not delimitation or a restricted and enclosed field marked off by definable limits; nor is it a space which increasingly provokes modern man, as Heidegger saw it, or a space which overwhelms man with fear and anguish, echoing Goethe. Landscape cannot be reduced to mere territory, in other words, an expanse of the earth's surface which remains the same throughout the changes in the environment. Nor can it be represented by territory, as man and nature have organized it for life, in other words, a biological, historical and cultural heritage to save and preserve.

Landscape cannot even be identified with the environment. As Rosario Assunto (Paesaggio, Ambiente, Territorio) reminds us, landscape is form, a complex pattern of forms bound up with the tradition and myth of the original garden, with the search for a beatutilul place (entopia), with the mirage of happiness (endaimonia), with the attainment of a paradise of mirabilia. 
Assunto (I/ paesaggio e lestelica) hats the merit of having elaloorated a new interpretative method which, ly comparing literature and philosophy, aims at a global and comparative approach, within a European rision, returning Italian studies to their rightful place. This allows us to set side by side. authors like Foscolo and Schiller. Cicognara and Keats, Schelling and Leopardi. Winckelmann and Aurelio De Giorgi Bertola. His analysis of the aesthetic categories has been very useful in order to understand the intricate conceptual web which gave raise to Modern European aesthetic taste.

Nature contains a varied canon of possible changes in time and spáce. When designing gardens, making improvements to the environment. or planning cultivations, men acknowleclge the art of nature and establish an interactive relationship with it; in other words, a poietic dialogue begins. Man acts with inventiveness, interpreting phenomena and things through imitative and symbolic processes which highlight a sense of wonder, as in the case of artificial grottoes, waterfalls, and walterways.

The landscape is a work of art not only because it is the object of man's work and skill, but because its arrangement appears as a natural product of forms. The things around us live on man's feeling. We perceive, imagine and shape at the same time. In enjoying and contemplating landscape. we become artists who perceive it as an aesthetic experience. Thus the aesthetics of landscape as such cannot prescind from the analysis of movement viewed as one of the qualifying aspects of nature, the artist of the cosmos, together with man, the artist of feeling. The landscape in fact presents itself according to mutable events shaped by the seasons, meteorological elements, winds and the action of the elements: earth. water, air and fire. Nature is the creator of mutable events.

We have discussed the origin of the aesthetics of landscape, the European vision of the conceptual and sentimental map representing it, the contribution of Italian studies at the turn of the $19^{\text {th }}$ century, the theory of landscape as an alesthetic icleal proposed by Assunto and recently reproposed in a new interpretation by Venturi Ferriolo, the institution of a true aesthetics of landscape. Before ecological disasters and the degradation of city and countryside, before the tormented and anguishing image of places once filled with beauty. I will close with Giacomo Leopardi prophetic words: "Noi siamo del tutto alienati dalla natura, e quindi infelicissimi" (Zibaldone. $81+, 19$ marzo $1821)$. 


\section{NOTES}

${ }^{1}$ Francesco Petrarca: " Dapprima, intimamente colpito da quella brezza pura e sottile che mai avevo provato e dallo spaziare più libero e vasto dello sguardo rimasi immobile, come stupefatto. Mi guardo intorno: le nubi sotto i miei piedi, e già meno incredibili erano divenuti per me il Monte Athos e l'Olimpo, poi che vedo in un monte di minor fama quei caratteri che avevo letto e udito essere attribuiti ad essi. Poi, rivolgo gli sguardi verso l'Italia, là dove più tende l'anima mia: ed ecco le Alpi, coperte di ghiacci e di nevi, attraverso le quali, un tempo, quel feroce nemico del popolo romano passò, con aceto, se vogliamo credere a quel che si racconta, frangendo le rupi; e vicine mi parvero, sebbene siano tanto lontane". L'ascensione al monte tentoso, 26 aprile 1336 (inizio della lettera).

${ }^{2}$ Torquato Tasso: "Poi che gli aviluppati calli / in lieto aspetto il bel giardin saperse:/acque stagnanti, mobili cristalli./ fior vari e varie piante, erbe diverse, /apriche collinette, ombrose valli./selve e spelonche in una vista offerse; /e quel che 'l bello e 'I caro accresce a lopre,/larte, che tutto fa, nulla si scuopre. /Stimi (sì misto il culto è co 'l negletto)/sol naturali e gli ornamenti e i siti./ Di natura arte par, che per diletto/ l'imitatrice sua scherzando imiti. Gerusalemme liberata, c. 16, 9-10. The response to these themes in Eighteenth Century England was important; however we must recall that in his remarks to the translation of Walpole History of the Modern Taste in Gardening A.W. Schlegel, along with other German philosophers, notices the Italian Renaissance influence, particularly of Tasso, as opposed to Walpole. Pindemonte, on the other end, stated: "Larte de' giardini irregolari si propone d'imitare, abbellendola, la natura...e si serve della stessa materia ond'è composto l'originale. (p.259).... L'arte del giardiniere inglese consiste nell'abbellire così un terreno assai vasto, che sembrar possa che la natura l'abbia in quella guisa abbellito ella stessa: ma la natura intesa a far cosa, più squisita e compiuta, che far non le veggiamo comunemente, riunendo in un dato spazio molte bellezze che non suole riunir mai, e dando a quelle bellezze stesse una perfezione e un finimento maggiore" (257).

${ }^{3}$ The concept of artem celare carries the echo of Arcadia whose sentiment of nature was to be close to the Eitheenth Century Europeans. In this connection the Epilogo of Arcadia by Jacopo Sannazzaro prouves illuminating: " Le nostre Muse sono estinte: /secchi sono i nostri lauri:/ rovinato è il nostro Parnaso: Le selve sono tutte mutate:/le valli e i monti per doglia/ sono divenuti sordi: non si trovano più Ninfe o Satiri per/ li boschi: i pastori hanno perduto il cantare".

\section{WORKS CITED}

Assunto R., Introduzione alla critica del paesaggio; in "De Homine", N. 5, 6, 1963. Il paesaggio come oggetlo estetico: in "Il Verri", n. 29, 1968.

Paesaggio. Ambiente, Territorio. L'u tentatiro di precisazione concettuale, "Bollettino del Centro Internazionale di Stucli di Architettura Andrea Palladio", XVIII, Vicenza 1976.

Tre saggi di estetica sul paesaggio del Settecento. Novecento. Palermo 1984.

La natura. le arti, la storia. Fsercizi di estetica, Guerini, Milano 1990.

Il paesaggio e lestetica (19-3), Novecento, Palermo 1994.

Baltrusaitis J., Jardins, pays dillusion. AA. IT., Jardins en France 1760-1820, Paris, 
1977; in Aberations, Flammarion, Paris 1983.

Banfi A., Iita dell arte. Studi di Estetica e Filosofia dell Arte ("bellezzal naturale"), al cura di E. Nattioli e G. Scaramuzza, Opere, Istituto) A.Banfi, Reggio Emilia, 1988.

Bassile, B., Ippolito P'indemonte é i giardini inglesi, "Filologia e critica" 6, 1981, p.329365.

Bertòla De Giorgi, A., Viaggio sul Reno (1790-1795), Prefazione di P. Monelli, De Agostini. Novaral 1963.

Burke E., A Pbilosopbical Inquiry into the Origins of On Idects of the Sublime and Beantiful (1757-59), Oxford U.P.,Oxford 1990.

Camporesi P., Le belle contrade. Nascita del paesaggio italiano, Garzanti, Milano 1992. Chambers, E., A Dissertation on Oriental Gardening (1773), Grillin, London 1779.

Clark K., Landscape into A\%, John Murray, London 19.49.

Cozens A., A New Metbod of Assisting the mention in Drawing Original Compositions of Landscape (1785), a cura di P.Lavezzari, Canova, Treviso 1981.

Croce., B., Aestbetica in muce (1928), Laterza, Bari 1979, pp 34-38.

De Seta. C., ( a cura di), Il paesaggio, Storia d'llalia. Annali 5, Einaudi Torino 1982.

De Seta. C., Iedutisti e t'iaggiatori in Italia tra Settecento e Ottocento. Torino. Bollati Boringhieri 1999.

Gilpin W., Three Essays on the Picturesque to Which Is Added a Poem on Landscape Painting, Blamire, London 1782.

Girardin,R.L., De la composition des paysages et Promenade on itinéraire des Jardins dErmenonille (1788), postface de M.H. Conan, Du Champ Urbain, Paris 1979.

Goethe J.W. von, Lettere di Wolfgang Goethe alla Signora ton Stein (a cura di A. Spaini), 2 voll., Parenti, Firenze, 1959.

Hegel G.W.F., riaggio nelle alpi bermesi (1796), a cura di G.A. De Toni. Lubrina, Bergamo 1990.

Heidegger M., Die Kunst und der Ramm, Erker-Verlag. St. Gallen, 1969.

Hirschfeld, Ch., C.L. von, Theorie der Gartenkninst, (1779-85) 2 voll., Olms, Hildesheim 1973.

Kemal S., I.Gaskell (edited by), Landscape, Natmal Beanty and the Art, Cambridge U.P., Cambridge 1993.

Kerenyi K., Landschaft und Geist, in Apollon wn Niobe. Werke IV. 1980, pp. 80-92: trad. it. "Paesaggio e spirito", in La madomma ungherese di Verdasio. Palesaggi dello spirito e paesaggi dell anima (a cura di A. Ruchat), Dadò, Locarno 1996. pp. 17-32.

Klonk Ch., Science and the Perception of Nature. Yale U.P., New I Haven-London 1996.

Knigh R.P., An Analytical Inquiny into the Principles of Taste, Luke Hasard, London 1908 .

Leopardi,G., Zitaldone di pensieri, 3 voll.. G. Pacella ed., Galmanti, Milano 1993.

Lovejoy A.O., La grande catena dell essere (1936), Feltrinelli, Milano 1966.

Mabil, L., Cesarotti, M.. Malacarne, V., Operette di vari antori intorno ai giardini inglesi ussia moderni. Verona, I817.

Merleau Ponty M., Phénoménomenologie de la perception. Gallimard. Paris 1945.

Monk, S., The Sublime (1935), l Mil Reseatrch Press, Ann Arbor, Mich. 1962.

Momet. D. Le sentiment de la nathre en France de J.J.Roussean à Bernardin de Saint-Pierre (1907), Lenox Hill, New York1971.

Milani R., Il Pittoresco.Levoluzione del Guslo lra classico e romantico, Laterza. Bari 1996.

Pindemonte, I., Dissentazione su i giardini inglesi e sul merito di ciò all Ilalia (1792), in Opere complete, Napoli 1861.

Petrarca. Francesco. La lettera del léntoso, lamiliarimm Reram Libri IV. I.Prefazione 
di Andrea Zanzotto. Commento e note di Maura Formica e Michael Jacob. Verbanial. Tararà Editore 1996.

Price U., Essays onthe Picturesque, as Compared with the Subime and Beantiful, Robson, London 1798.

Ritter J. Landschaft Zur Funktion der Aesthetischen in der modernen Gesellschaft, Aschendorff, Munster 1963.

Roger A., Connt Traité clu palsage, Gallimard Paris 1997.

Rousseau J.J., Les retêries du promeneur solitaire (1782), Flammarion, Paris 1964.

Ruskin J.. Lectures on Landscape delizered at Oxford, London 1897.

Saint Girons B., Fiat lmx: Une philosophie du sublime Quai Voltaire, Paris 1993.

Salerno R., Archiettura e rappresentazione del paesaggio. Guerini, Milano 1995.

Saussure H.B. de, Jonmal d'un tolage à Chamonix et à la cime du Mont Blanc (1787), Lyon 1926.

Schinkel K.F., Architettura e paesaggio (a cura di M. Pogacnik), Motta, Milano 1992.

Schlegel,A.W., Historiche literarische und unterbaltend. Schriften. (Ueber die nenere

Gartenkumst ion Horatio Walpole), ubersetzt von A.W. Schlegel, Hartknoch,

Leipzig 1800, pp384-446.

Schwind M., Simn und Ausdruck der Landschaft. (1950), "Tellus", V. 14, 1995.

Shama. S.. Landscape and Memory, Fontana Press, London, 1996.

Silva. E. Dell arte dei giardini inglesi (1801), introd. Di G. Venturi, Longanesi, Milano 1976.

G. Simmel, Philosophie der Laudschaft (1912-13), ed.it., Il Lolto e il ritratto. Saggi sullarte, a cura di L. Perucchi. Il Mulino, Bologna, 1989.

Tasso. T., Gemsalemme liberata, a cura di L. Caretti, Laterza, Bari 1967.

Tiezzi E., Il capitombolo di Ulisse. Vuora Scienza. estetica della natura, stiluppo sostenibile. Feltrinelli, Milano 1991.

Tommaseo, N., Larte dei giardini in Bellezza e cinltà delle arti del bello sensibile, Le Monnier, Firenze 1857.

Tripet A. Ronssean et l'esthétique du pal'sage, "Annales de la Societé. J.J. Rousseau". n.3. 1990.

Váari. G., Le lite (1550). Einaudi, Torino 1986.

Venturi, G., Le scene dellEden. Teatro, ante, giardini nella letteratura italiana. Borolenta, Ferrara 1979.

Venturi Ferriolo M., Giardino e filosofia, Guerini, Milano 1992.

Giardino e paescrggio dei romantici, Guerini, Milano 1998.

Pittoresco e Romantico: nota sulla ricezione del giardino paesaggistico in Italia in Il giardino di villa in flalia nel XTIII e XZX secolo,a cura di E. Accati e M. Devecchi, Ace International, Torino 1995. pp 275-290.

Walpole. 11. The History of Hodern Taste in Gardening, 1771-85, Shakespeare, London 1827 (repr. Garland, New York-London 1982).

Weillacher U.. Between Landscape Architecture and Land An. Birkhauser, Boston 1996.

Yi-Fu Tuan, Homntains. Ruins and the Sentiment of Melancboly" "Landscape" Fall 1964. Pp. 27-30. 